UDC 811. 111'255

DOI https://doi.org/10.32841/2409-1154.2019.42.3.29

\author{
Kovalevska T. I., \\ Associate Professor at the Department of Foreign Philology and Translation \\ of the Vinnytsia Institute of Trade and Economics \\ of the Kyiv National University of Trade and Economics
}

\author{
Matsera O.A., \\ Senior Lecturer at the Department of Foreign Philology and Translation \\ Kyiv National University of Trade and Economics
}

\title{
GLOBASIZATION, LOCALIZATION AND GLOCALIZATION: AN INVESTIGATION INTO CULTURAL TRANSLATION
}

\begin{abstract}
Summary. The article is dedicated to comparing and contrasting the notions of globalization, localization and glocalization in frames of cultural translation. Local cultures are viewed in the article as struggling to redefine themselves as well as to reassert local identities within globalization. Globalization is seen in the article as not necessarily imposing cultural hegemony but rather linking a given local culture to outside cultures. Glocalization is discussed as phenomenon of globalization and localization overlapping and resulting into necessary adjustments made in the process of cultural translation.

Local disorientation is to some extend caused and increased by globalization, which is evidenced by displacement and realignment of the sovereign states responsible for many local crises. Thus, globalization threatens to reduce and even erase local difference as it is perceived as predetermined and unchanging at times. At the same time global unification inevitably leads to homogenization and local resistance.

Glocalization stands out as a hybrid form resulting from the undisputable influences localization makes on the conceptions of the world. Glocalization seems to be mirrored in trends for revitalization of endangered languages and cultures, threatened by the intrusion of global forces. In other words, people become more concerned with preserving the values of their communities as a reaction to global sameness. The struggle for cultural survival, culminating in the translator's efforts of cultural negotiation, tends to erase linguistic and cultural differences.

Localization inherent in translation apart for the purpose of intelligibility and readability stands out as an act of both language and culture transformation. Translation needs to take into account the wider context of events, circumstances an asymmetrical power relations.
\end{abstract}

Key words: the notion of globalization, the notion of localization, the concept of glocalization, cultural translation, cultural anxiety, alienation, redefining.

The issue under discussion. In an era of rapid globalization, the inevitable trend is that local cultureis re-situated as well as reestablished in the global context. Consequently, we are faced with a more complex relationship between local and global cultural discourses as reflected in translation, which in itself is a constant process of decolonization in its cultural reproduction open to cultural specifics inherent in a different tradition.

As globalization shrinks the world with a tendency towards sameness, localization multiplies cultures with a firm emphasis on difference. Globalization and localization are interdependent phenomena as twin forces representing two opposing perspectives on the world, and as a result, different cultures meet and clash because globalization brings diverse populations together in every aspect of communication and life $[1, p .6]$. Translation contributes significantly to universalism and hence, globalization.

Analysis of recent research and publications on the topic. While globalization transforms nations, localization transforms the world in the form of global cooperation, interconnecting the local and the global. Therefore, globalization and localization are both separable and inseparable at the same time. The problem of understandingculture as constitutive of globalization as well as its implication as to how weconceive of culture as having consequences has recently gained its fair place in the works of linguists and translators (F.E. Anderson, Z. Atalay, R.G. Ferguson, D. Johnston, S. Kelly, P. Lang, S. Maitland, A.G. Macedo, M.E. Pereira, R. Ritzer, V. Roudometov, Y. Sun).

Thus, the aim of this article is to highlight the concepts of localization and glocalization as a cultural translation and transformation practice aimed at mirroring the culture of the language in translation under the influence of all-penetrating globalization processes.

Basic material presentation.Falling trade barriers between nations have led to falling linguistic andcultural barriers, which in turn further promotes globalization. Whether consciously or unconsciously translation has created a circular globalizingtrend: global restructuring and colonial precedents bring potentialimplications to local identity resulting in the perceived assault of globalizationupon collective national spirit or personality becoming a constantsource of cultural anxiety [7, p. 14]. The rapid pace of globalization causes and increases local disorientationwith displacement and realignment ofthe sovereign states responsible for many local crises. Since globalizationis at times perceived as predetermined and unchanging, it threatensto reduce and even erase local difference.

Thus, local cultures struggleto redefine themselves, to reassert local identities within globalization,which also empower a reconstruction of a local sense of self, mediatedby the global. Meanwhile, foreign or global influences are reinterpretedor internalized as part of localization practices.In this respect the issue of glocalization is gaining usage as being at the crossroads of globalization and localization [6, p. 118].

The concept of glocalization suggests that as the various cultures of the world become outwardly more similar as seen in such domains as food culture, pop music, and the widespread use of English 
as an international language, they simultaneously develop local adaptations of the globalized products. In other words, the menus of McDonald's or Starbucks, or the rhythms and themes of pop songs, will be adapted to local audiences based on local values and culture even while adhering to a global template [2, p. 44]. Similarly, English develops into new localized varieties as its learning and use become more and more widespread. Glocalization breaks down commonly perceived dichotomies such as those of universal vs particularistic and homogeneous vs. heterogeneous. Although it is not often mentioned in the same light, the process of glocalization would also seem to be reflected in movements toward revitalization of endangered languages and cultures that are threatened by the intrusion of global forces; that is, as a reaction to global sameness, people become more concerned with preserving the values of their communities [1, p. 4].

It is important to stress that global unification leads to homogenizationand local resistance. Diversification and heterogenization become increasingly desirable in order to reduce continuous political conflictsand cultural tensions. Developed and developing countries respond differentlyto globalization in different stages of historical development.

There is no doubt that localization influences conceptions of theworld, and the resultis a hybrid form of glocalization.

But the real question is how localization varies and changes in different timesand places in relation to broader political, social, and cultural power.

Localization inherent in translation is not just for the purpose of intelligibilityand readability but also, more significantly, constitutes an actof transformation regarding both language and culture. In producingadaptation to another use, translation needs to take wider contextualimport into consideration as is dictated by events, circumstances, and above all, asymmetrical power relations. The temporality as opposed to permanenceof any localization strategy represents a significant feature of the cultural translation experience. Translation cannot be separated from power relations, social setting, political context, andcultural paradigm [8, p. 11]. With the unequalpower relations between the global and the local awareness, translation is boundto be culturally or politically polarized with differing interests being demonstrablyat odds with one another. The effort of culturalnegotiation on the part of the translator culminates the struggle for culturalsurvival, and thus tends to erase the difference of languages and cultures.

The waysin which translation is conducted, not to mention whattexts are selected for translation, are closely related to the risk of hostilityand alienation, thus, it often lies within the competence of a translatorto exercise the practical function of localization [3, p. 148]. In general, however,excessive localization regarding translation leads to de-alienation, whichmay be enforced by either cultural superiority or cultural inferiority.In the former case, the target culture is too complacent to let foreigncultural values come into play in translation whereas in the latter, fear ofcultural erosion engenders indigenous resistance to foreign or global culturalimpositions. The pressure of the local cultural, political and socialcontext causes translation to go through varying degrees of localizationin its interaction with what is imported through the exertion of culturalpower. To be sure, translation reflects and alters specific cultural power structures involved in the process of textual transfer so as to affect the outcome of globalization [4, p. 68]. Cross-cultural negotiation lays bare the powerrelations at work in the target system, since power determines the levelof intervention and manipulation on the part of the translator in a bidto negotiate more favourable or less unfavourable terminologies. It is clear that the more powerful side is likely to exercise more influence.Localization seems so intimately related to translation that some researchers go as far as to suggest that translation theory can bereconsidered as localization theory [8, p. 18].

Translation moves the text to betranslated into the globalization/ localization continuum, and in a way,globalization and localization undergo more or less the same processand show a tendency towards a culturally rich conflation. Aside from itsdanger of cultural hegemony, globalization brings different local culturestogether, which can be construed as a positive step toward collaborativeand constructive relationships. Globalization does not necessarily resultin an imposed cultural hegemony but can link a given local culture tooutside cultures. Rather than destroy local culture, exterior cultures provideopportunities for its growth. In this ever-changing interconnected age, local practices are often driven by local interests. Thus, the culturallyunacceptable can be easily turned into the culturally inaccessibledespite, or because of, translation. Also, it is possible that local cultureis transmitted to the translated text so as to create a hybridized culturalproduct. Particularly, in translating out of the translator's native languagefrom a local culture, the translator may consciously or unconsciouslyleave discursive features of the local culture in the translated textas detectable cultural traces [5, p. 94].

It is quite typical for the translationtext to be rewritten and rearranged in order to be suitably acclimatized for a local target audience. When it includes imprints of local culture, a given translated text isless unfamiliar and de-alienated to some extent. It should be pointed out that localization is different from domestication and often exceeds it, since domestication strategy is mainly implemented in the translation practice in a technical sensepresenting a smoothing exercise deprived of any drastic changes, such as deletion, additionor radical alteration. Both localization and domestication pursueintegration into the target culture, but the end product of domesticationremains essentially untransformed [8, p. 8].

Localization assumes a more systematic, conceptual, dynamic interaction and exchange between the two cultural systems comprising values, conceptions, beliefs and experiences. Localization as manifest in translation is an act of erasure and projection with regard to local culture in the global context. Local culture is rooted in its tradition, and when confronted with a foreign cultural representation in translation, it is forced to react to cultural otherness.

Many contextual details concerning cultural specifics in both source and target texts are intertwined, and the complex interrelations between the two represented cultural systems prompt the translator to engage in cross-cultural negotiations.

Translation plays a key role in promoting both globalization and localizationin that it calls for the recognition of the value of other culturesand the limits of local culture. New identities of shared attributes involving the local community emerge in an increasingly globalized world [5, p. 45].

The homogenization of culture informed by the dominance of Englisharound the world is at the root of the fear of globalization. Globalizationhas relentlessly eroded on local culture and its identity due to the widespreaduse of English. Significantly, the use of English by non-native speakers can glocalize it as in the case of Singaporean 
English with itslocal identity as a distinctive part of the language. Glocalization is also widely evident in local languages being translated into English. There is a good chance that "glocal Englishes" are created as a result, particularly if the target language is not the native language of the translator [5, p. 17]. Such local identities, as redefined within the conceptual framework of glocalization, are reinforced in many ways. Indicating the desire to reach out for the purpose of selfexpansion, translation invites and introduces differenceand in doing so, allows or forces "self" to interact with "other."

Since it centreson adaptation and transformation localization is championed in response to what is perceived as colonizing and postcolonial foreigninvasion. The currentglocalizationdiscourse gains importance when the interplay between deterritorialization and reterritorialization is powerful. It is, therefore, crucial to investigate cultural and politicaltensions in the process oftranslation in the cross-cultural context of glocalization [4, p. 25].

It is very tempting for translation to localize, making connections with local realities, and increasing relevance to local needs. Yet local culture is not automatically connected with outside cultures, and although local knowledge may sometimes impede understanding foreign otherness, it can also help improve translation results. How localization affects translation strategies and the reception of translation must be addressed because local concerns, issues, and problems, through translation, are related to each other, in various ways, and to the outside world as a means of cultural dialogue. Local knowledge, therefore, is of particular relevance to translation.

Moreover, localization is a sign of assuming some kind of editorial control of the text in translation not only to prevent the negation of the value of local culture, but also to enhance accessibility, which reflects the reality of the fundamental problem of cross-cultural engagement. Nevertheless, despite the necessity for resorting to localization in translation, the long-term disadvantage and danger of unrestrained localization are only too obvious. After all, it is only a superficial measure to counterbalance the possible impact of alienating the target reader, and in the long run, such a measure presents an impediment to translation as a means of crosscultural exchange [8, p. 19].

Conclusions. It is doubtful that translation will amount to a unified global cultural discourse; it mediates between different cultural traditions, necessitating a cultural dialogue under globalization and fostering cultural diversity, which acts as a perfect antidote to cultural homogeneity. In the process of glocalization, cultural identity is constantly reinvented and globalism adapted to local reality. In addition, effective localization requires global knowledge just as localization ironically also helps promote globalization. Such a process is much about accessibility, namely making things easy to be accepted on local terms by the local while preserving "selves" subject to change and transformation.

\section{References:}

1. Anderson F.E. Glocalization, English and Education in languages of lesser power. URL: https://www.kansai-u.ac.jp/Tozaiken/publication/ asset/bulletin/46/kiyo4609.pdf.

2. Ferguson R.G. English as a GloCalization Phenomenon. Observations from a linguistic microcosm. Universitat de Valencia, 2011. 280 p.
3. Kelly S., Johnston D. Betwixt and Between: Place and Cultural Translation. Cambridge Scholars Publishing, 2009. 297 p.

4. Macedo A.G., Pereira M.E., Lang P. Identity and Cultural Translation: Writing Across the Borders of Englishness: Women's Writing in English in a European Context. Peter Lang, 2006. 282 p.

5. Maitland S. What Is Cultural Translation? Bloomsbury Publishing, 2017. $192 \mathrm{p}$.

6. Ritzer R. Atalay Z. Readings in Globalization: Key concepts and Major debates. John Wiley \& Sons, 2010. 488 p.

7. Roudometov V. Glocalization: a Critical Introduction. Routledge, 2016. $188 \mathrm{p}$.

8. Sun Y. Cultural transation in the context of glocalization. URL: https://commons.ln.edu.hk/sw_master/676/.

Ковалевська Т., Мацера О. Глобалізація, локалізація та глокалізація: дослідження в культурологічному перекладі

Анотація. Стаття присвячена порівнянню та зіставленню понять глобалізації, локалізації та глокалізації в контексті культурологічного аспекту перекладу. У статті місцева культура бачиться як боротьба за переосмислення своєї культурної ідентичності, щоб заново утвердити іii в контексті глобалізації. Глобалізація потрактовується у статті не як безумовне нав'язування культурної гегемонії місцевій культурі, а, радше, як місток між місцевою культурою та зовнішніми культурами. Глокалізація постає як явище на перетині глобалізації та локалізації, яке спричиняє необхідність внесення корективів у процес культурологічного перекладу.

Локальна дезорієнтація певною мірою спричинена і посилюється глобалізацією, про що свідчать переміщення та перестановка суверенних держав, що несуть відповідальність за численні локальні кризи. Таким чином, глобалізація загрожує розмити та навіть стерти локальні відмінності, оскільки вона сприймається як неминуча та незмінна. Водночас глобальне об'єднання неминуче призводить до гомогенізації та місцевого опору.

Глокалізація постає як гібридна форма, що виникає внаслідок беззаперечних впливів, які локалізація чинить на світоглядні уявлення. Схоже, що глобалізація відображена в тенденціях пожвавлення зникаючих мов і культур, загрожує вторгненням глобальних сил. Іншими словами, те, що люди переймаються збереженням цінностей своїх культурних спільнот, $є$ реакцією на глобальну однаковість. Боротьба за культурне виживання, що позначна зусиллями перекладача як медіаора культурних переговорів, тяжіє до усунення мовних і культурних відмінностей.

Вплив локалізації на стратегії перекладу та на сприйняття перекладу носіями цільової мови та культури слід враховувати, адже місцеві проблеми, виклики та реалії транслюються зовнішньому світу саме через переклад, який перетворюється, таким чином, на засіб культурного діалогу.

Локалізація, притаманна перекладу, покликана сприяти зрозумілості та читабельності. Окрім того, вона виступає як акт трансформації мови та культури. Переклад повинен враховувати ширший контекст подій, обставини, асиметричних відносин влади.

Ключові слова: поняття глобалізації, поняття локалізації, поняття глокалізації, культурологічний переклад, культурне занепокоєння, відчуження, переосмислення. 